Original Research

\title{
Influence of Biochar Application on Reduced Acidification of Sandy Soil, Increased Cation Exchange Capacity, and the Content of Available Forms of K, Mg, and P
}

\author{
Krzysztof Gondek ${ }^{1 *}$, Monika Mierzwa-Hersztek ${ }^{1}$, Michał Kopeć1, \\ Jakub Sikora ${ }^{2}$, Tomasz Głąb ${ }^{3}$, Katarzyna Szczurowska ${ }^{1}$ \\ ${ }^{1}$ University of Agriculture in Krakow, Department of Agricultural and Environmental Chemistry, Kraków, Poland \\ ${ }^{2}$ University of Agriculture in Krakow, Institute of Agricultural Engineering and Informatics, Kraków, Poland \\ ${ }^{3}$ University of Agriculture in Krakow, Institute of Machinery Exploitation, Ergonomics and Production Processes, \\ Kraków, Poland
}

Received: 15 November 2017

Accepted: 2 January 2018

\begin{abstract}
Fertilisation has the greatest impact on soil properties, and they in turn decide on the conversion and availability of fertilising compounds. The aim of the tests was to evaluate the influence of low-temperature $\left(300^{\circ} \mathrm{C}\right)$ conversion of pig manure and poultry litter on (i) $\mathrm{K}, \mathrm{Mg}$, and $\mathrm{P}$ contents in biochars and (ii) reduction of acidification, cation exchange capacity, and availability of $\mathrm{K}, \mathrm{Mg}$, and $\mathrm{P}$ in sandy soil after their application. The tests were conducted in laboratory conditions using $0.5 \%, 1 \%$, and $2 \%$ addition of pig manure, poultry litter, or biochars. Thermal conversion of pig manure and poultry litter increased the content of total forms of $\mathrm{K}, \mathrm{Mg}$, and $\mathrm{P}$ in biochars and did not significantly increase the content of these elements extracted by water. The introduction of organic materials into the soil, in particular biochar, caused significant reduction in soil acidification and an increase in cation exchange capacity. The contents of available potassium and magnesium increased together with the increase in dose of pig manure-derived and poultry litter-derived biochars. No available forms of phosphorus were found in the soil into which lower $(0.5 \%$ and $1 \%)$ doses of biochar were introduced. Only the highest (2\%) dose of biochars and poultry litter caused the release of available $\mathrm{P}$.
\end{abstract}

Keywords: biochar, poultry litter, pig manure, soil, cation exchange capacity, potassium, magnesium, phosphorus

*e-mail: k.gondek@ur.krakow.pl 


\section{Introduction}

The underlying aim of agriculture is to produce proper quality food. This effect can be achieved through balanced fertilisation, selection of plant varieties, and adequate agricultural engineering. Failure to adopt a well-thought-out application of fertilisers and organic waste materials for soil and plant fertilisation may entail a serious threat to the natural environment (purity of soil and water, and quality of plant yields) [1-3]. These threats may result mainly from losses of nutrients introduced into the soil, as well as their excessive accumulation in plant yields.

Although the application of animal fertilisers as nutrients for plants is a worldwide accepted practice, there is still a need to assess their potential influence on chemical properties of soil, including sorption properties and content of available forms of nutrients. Environmental concerns raised by the use of excessive doses of poultry litter or pig manure are mainly connected with their diverse and unstable chemical composition and level of mineralisation, which may result in different availability of nutrients for plats [4-8]. Therefore, more and more attention is paid to the proper processing of these materials into, for example, biochar, and then their adequate application.

Many scientists show great interest in biochar perceived as material that improves soil properties through the reduction of acidification, decrease of bulk density, enhancement of retention, and cation exchange capacity (CEC) of soil [9-10]. Alternatively, the application of biochar into the soil may not produce any effect [11]. Hence, the biochar's effect in the soil depends on several factors: material used for the production of biochar, time and temperature of pyrolysis, and soil type [12]. Taking into account the thermal conversion of organic materials, such as poultry litter and pig manure, one should expect not only changes in their physical properties, but above all changes in their chemical composition. The introduction of biochars into the soil may initiate a series of mechanisms, including oxidation, decomposition, and carboxylation, which will significantly control its transformations [13].

Changes in the chemical composition of biochars are related not only to the content of nutrients for plants, but also relationship between the total content of element and total content of available forms. Information on the content of available forms of macronutrients can substantially contribute to the correct dosing of biochars and minimise the risk of dispersion of element unused by plants in the environment. Undoubtedly, the application of biochar contributes to improved sorption properties of soil, and thus to the retention of nutrients, minimising their losses by leaching [1, 8, 12-15]. The results from numerous tests have shown that biochars may increase the content of soil organic matter, and in particular extracted organic carbon [16]. In addition, they may increase the biomass of soil microorganisms and stimulate their enzymatic activity $[12,17]$. In the longer term, the beneficial effects of biochar application in the soil decide on its fertility and productivity.

The effect of fertilisation on the quantity and quality of plant yields is strongly dependent on soil properties. Fertilisation has the greatest impact on soil properties, and they in turn decide on the conversion and availability of fertilising compounds. Therefore, the aim of the tests was to evaluate the influence of low-temperature $\left(300^{\circ} \mathrm{C}\right)$ conversion of pig manure and poultry litter on (i) $\mathrm{K}, \mathrm{Mg}$, and $\mathrm{P}$ contents in biochars, and the (ii) reduction of acidification, cation exchange capacity, and availability of $\mathrm{K}, \mathrm{Mg}$, and $\mathrm{P}$ in sandy soil after their application.

\section{Material and Methods}

\section{Soil and Amendments}

The tests were carried out on soil collected from the 0-0.2 m layer in southern Poland. The properties of the soil used in the tests are presented in Table 1.

The process of thermal conversion of pig manure (PM) and poultry litter (PL) was carried out in laboratory conditions using a test stand for thermal conversion of biomass under a limited supply of air (1-2\%) [18]. Temperature in the combustion chamber was $300 \pm 10^{\circ} \mathrm{C}$. The rate of heating the combustion chamber was $10^{\circ} \mathrm{C} \cdot \mathrm{min}^{-1}$. The pyrolysis time and temperature were established on the basis of our own preliminary examinations and results reported in literature [19-23].

In order to identify the properties of the substances used in the tests - pig manure (PM), pig manure-derived biochar (PMB), poultry litter (PL), and poultry litterderived biochar (PLB) - the materials were ground in a laboratory mill (1 $\mathrm{mm}$ sieve mesh diameter), dried at $105^{\circ} \mathrm{C}$ for 12 hours [24], and analysed. The $\mathrm{pH}$ of materials (material:water $=1: 5$ ) was electrochemically determined using a $\mathrm{pH}$ meter $(\mathrm{pH}-$ meter $\mathrm{CP}-505)$, electrical conductivity (material:water $=1: 5$ ) using a conductivity meter (conductivity/oxygen meter CCO - 501) [25], the total contents of total forms of nitrogen and carbon were determined using a CNS analyser (Vario MAX Cube manufactured by Elementar). Total potassium, magnesium, and phosphorus contents were determined after ashing the sample in a chamber furnace at $450^{\circ} \mathrm{C}$ for 12 hours and mineralising its residues in a mixture of concentrated nitric and perchloric acids (3:2) (v/v) [26]. After 24-hour extraction (at room temperature), the water-soluble forms of $\mathrm{K}$, $\mathrm{Mg}$, and $\mathrm{P}$ (material:water $=1: 5$ ) were also determined for organic materials [21]. The concentration of analysed elements in the resulting solutions and extracts was determined by inductively coupled plasma optical emission spectroscopy (ICP-OES, Perkin Elmer Optima 7300 DV). Specific surface area $\left(\mathrm{S}_{\mathrm{BET}}\right)$ of organic materials, as well as pore volume and diameter, were 
Table 1. Selected chemical and physical properties of soil.

\begin{tabular}{|c|c|c|}
\hline $\mathrm{pH} \mathrm{H} \mathrm{O}^{\mathrm{O}}$ & - & $5.79 \pm 0.07$ \\
\hline $\mathrm{pH} \mathrm{KCl}$ & - & $4.60 \pm 0.01$ \\
\hline Electrical conductivity (EC) & $\mu \mathrm{S} \cdot \mathrm{cm}^{-1}$ & $21.0 \pm 9.0$ \\
\hline $\begin{array}{c}\text { Cation exchange capacity } \\
\text { (CEC) }\end{array}$ & $\mathrm{mmol}(+) \cdot \mathrm{kg}^{-1}$ & $79.1 \pm 7.0$ \\
\hline Hydrolytic acidity (Hh) & $\mathrm{mmol}(+) \cdot \mathrm{kg}^{-1}$ & $21.6 \pm 2.1$ \\
\hline Soil Organic Carbon & $\mathrm{g} \cdot \mathrm{kg}^{-1}$ & $4.20 \pm 0.10$ \\
\hline Total Nitrogen & $\mathrm{g} \cdot \mathrm{kg}^{-1}$ & $0.87 \pm 0.04$ \\
\hline Total Potassium & $\mathrm{g} \cdot \mathrm{kg}^{-1}$ & $0.81 \pm 0.08$ \\
\hline K-CaCl 2 & $\mathrm{mg} \cdot \mathrm{kg}^{-1}$ & $11.1 \pm 0.6$ \\
\hline Total Magnesium & $\mathrm{g} \cdot \mathrm{kg}^{-1}$ & $0.28 \pm 0.01$ \\
\hline Mg-CaCl & $\mathrm{mg} \cdot \mathrm{kg}^{-1}$ & $45.8 \pm 0.4$ \\
\hline Total Phosphorus & $\mathrm{g} \cdot \mathrm{kg}^{-1}$ & $0.17 \pm 0.00$ \\
\hline P-CaCl & $\mathrm{mg} \cdot \mathrm{kg}^{-1}$ & $\mathrm{n} . \mathrm{d}^{\mathrm{a}}{ }^{-1}$ \\
\hline Sand & $\mathrm{g} \cdot \mathrm{kg}^{-1}$ & $870 \pm 56$ \\
\hline Silt & $\mathrm{g} \cdot \mathrm{kg}^{-1}$ & $80 \pm 6$ \\
\hline Clay & $\mathrm{g} \cdot \mathrm{kg}^{-1}$ & $50 \pm 4$ \\
\hline
\end{tabular}

Each value represents the mean of three replicates \pm standard deviation

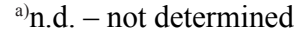

determined using a multifunction accelerated surface area and porosimetry analyser ASAP 2010 manufactured by Micromeritics (USA). Specific surface area $\left(\mathrm{S}_{\mathrm{BET}}\right)$ was determined by physical nitrogen adsorption at liquid nitrogen temperature $\left(77^{\circ} \mathrm{K}\right)$ using BrunauerEmmet-Teller equation. Before measuring specific surface area $\left(\mathrm{S}_{\mathrm{BET}}\right)$, test samples were subjected to desorption at $105^{\circ} \mathrm{C}$ under vacuum conditions and washed with pure helium. Sample degassing time was 16 hours. The status of surface degassing was controlled in an automatic manner [27].

\section{Soil pH, CEC, and BS}

Incubation tests were conducted on $100 \mathrm{~g}$ analytical samples of soil with $0.5 \%, 1 \%$, and $2 \%$ of abovementioned organic materials: PM, PMB, PL, PLB. Moisture content in the sample was maintained at $60 \%$ of soil water capacity. The control sample was stored with no organic materials added. The incubation of soil samples was carried out for 150 days at $25^{\circ} \mathrm{C} \pm 0.10$. After incubation, the following was determined in the samples: soil $\mathrm{pH}$ - by potentiometric method - in the suspensions of soil and water, and soil and $1 \mathrm{M}$ solution of $\mathrm{KCl}$ (soil:solution = 1:2.5). The sum of exchangeable alkaline cations (EAC) and hydrolytic acidity (Hh) were determined by Kappen method [28]. Cation exchange capacity (CEC) and base saturation (BS) percentage were then calculated as follows:

$$
\begin{aligned}
\mathrm{CEC} & =\mathrm{Hh}+\mathrm{EAC} \\
\mathrm{BS}(\%) & =\frac{\mathrm{EAC}}{\mathrm{CEC}} \times 100
\end{aligned}
$$

\section{Assimilable P, K, and Mg Contents in Soil}

The available forms of $\mathrm{P}, \mathrm{K}$, and $\mathrm{Mg}$ were extracted from soil with $0.01 \mathrm{M}$ solution of $\mathrm{CaCl}_{2}$ (soil:solution $=1: 10$ ) for 2 hours [29].

The analysed elements in the resulting extracts were determined by inductively coupled plasma optical emission spectroscopy (ICP-OES, Perkin Elmer Optima 7300 DV).

\section{Statistical Analysis}

The experiment was performed in three replicates. The obtained data were compiled with the use of STATISTICA 12 (StatSoft Inc.). The mean values of analysed properties were compared using Tukey's multiple comparison test at $\mathrm{p} \leq 0.05$. Variations in the properties were determined by calculating the standard deviation $( \pm \mathrm{SD})$.

\section{Results and Discussion}

\section{Characteristics of Organic Materials and Soil}

For pig manure (PM) and poultry litter (PL), the observed values of $\mathrm{pH}$ and electrical conductivity (EC) were lower compared to biochars derived from these materials (BPM, BPL) (Table 2). In pig manure-derived biochar (BPM) and poultry litter-derived biochar (BPL), the reported $\mathrm{N}, \mathrm{C}, \mathrm{K}, \mathrm{P}$, and $\mathrm{Mg}$ contents were higher in comparison with materials not subjected to pyrolysis. The determined specific surface area, pore diameter, and volume in biochars (BPM, BPL) were higher than in materials not subjected to pyrolysis.

The soil used in the tests was sandy and acidic, whose $\mathrm{Hh}$ and $\mathrm{CEC}$ values were $21.6 \mathrm{mmol}(+) \cdot \mathrm{kg}^{-1}$ and $79.1 \mathrm{mmol}(+) \cdot \mathrm{kg}^{-1}$, respectively (Table 1$)$. The contents of available forms of potassium and magnesium were $11.1 \mathrm{mg} \mathrm{K} \cdot \mathrm{kg}^{-1}$ and $45.8 \mathrm{mg} \mathrm{Mg} \cdot \mathrm{kg}^{-1}$, respectively. No available forms of phosphorus were determined in the soil before the tests (Table 1).

\section{$\mathrm{K}, \mathrm{Mg}$, and $\mathrm{P}$ Contents in Pig Manure, Poultry Litter, and Biochars}

The content of total forms of potassium in pig manure (PM) was lower than in poultry litter (PL) (Table 3). The content of that form of $\mathrm{K}$ in biochars was significantly higher. In the case of BPM, the increase in $\mathrm{K}$ content in relation to PM was almost $100 \%$, and in the case of PL and BPL, over 64\%. Thermal conversion of PM and PL resulted in the increased content of water-extracted forms of $\mathrm{K}$. 
Table 2. Selected properties of organic materials.

\begin{tabular}{|c|c|c|c|c|}
\hline Determination & $\begin{array}{c}\text { Pig manure } \\
(\mathrm{PM})\end{array}$ & $\begin{array}{c}\text { Pig manure }- \text { derived } \\
\text { biochar }(\mathrm{BPM})\end{array}$ & $\begin{array}{c}\text { Poultry litter } \\
(\mathrm{PL})\end{array}$ & $\begin{array}{c}\text { Poultry litter }- \text { derived } \\
\text { biochar }(\mathrm{BPL})\end{array}$ \\
\hline Dry matter $(\%)$ & $17.8 \pm 0.1$ & $97.9 \pm 0.2$ & $32.3 \pm 1.7$ & $98.6 \pm 0.2$ \\
\hline $\mathrm{pH}\left(\mathrm{H}_{2} \mathrm{O}\right)$ & $7.56 \pm 0.01$ & $8.32 \pm 0.00$ & $7.53 \pm 0.02$ & $8.41 \pm 0.02$ \\
\hline Electrical conductivity EC $\left(\mu \mathrm{S} \cdot \mathrm{cm}^{-1}\right)$ & $20.3 \pm 3.6$ & $77.7 \pm 17.8$ & $49.1 \pm 12.4$ & $91.5 \pm 2.6$ \\
\hline Nitrogen $\left(\mathrm{g} \cdot \mathrm{kg}^{-1}\right)$ & $31.4 \pm 0.4$ & $34.9 \pm 0.5$ & $25.1 \pm 1.7$ & $32.7 \pm 0.7$ \\
\hline Carbon $\left(\mathrm{g} \cdot \mathrm{kg}^{-1}\right)$ & $370 \pm 3$ & $398 \pm 6$ & $323 \pm 3$ & $377 \pm 3$ \\
\hline Specific surface area $\mathrm{S}_{\mathrm{BET}}\left(\mathrm{m}^{2} \cdot \mathrm{g}^{-1}\right)$ & $1.62 \pm 0.10$ & $2.05 \pm 0.19$ & $1.83 \pm 0.22$ & $2.76 \pm 0.29$ \\
\hline Pore volume $\left(\mathrm{cm}^{3} \cdot \mathrm{g}^{-1}\right)$ & $0.007 \pm 0.000$ & $0.008 \pm 0.001$ & $0.006 \pm 0.000$ & $0.011 \pm 0.002$ \\
\hline Pore diameter $(\mathrm{nm})$ & $15 \pm 1$ & $21 \pm 3$ & $14 \pm 2$ & $18 \pm 3$ \\
\hline
\end{tabular}

Each value represents the mean of three replicates \pm standard deviation

The content of total forms of magnesium in analysed materials was higher than determined potassium contents (Table 3). The content of potassium extracted with water from organic materials turned out to be relatively lower. As a result of thermal conversion of organic materials, the content of water-extracted $\mathrm{Mg}$ forms has decreased. The share of water-extracted forms of $\mathrm{Mg}$ in total magnesium content was larger for both pig manure (PM) and pig manure-derived biochar (BPM).

Thermal conversion of both materials (PM, PL) caused an increase in the content of total forms of P (Table 3). The observed number of total $\mathrm{P}$ forms in poultry litter (PL) and poultry litter-derived biochar (BPL) was higher compared to pig manure (PM) and pig manure-derived biochar (BPM). As a result of thermal conversion, the observed contents of water-extracted forms of $\mathrm{P}$ in both biochars (BPM, BPL) were lower in comparison with non-converted materials.

According to Gaskin et al. [30], mineral composition of biochars is contingent upon the type of substrate used in the process. The above authors confirm an increase in the contents of elements such as potassium and magnesium, while at the same time showing that the use of higher temperature results in an increased mineral content in biochar, which is due to the loss of organic substances. As stated by Wang et al. [31], thermal conversion of poultry litter gives more stable forms of phosphorus, which may result in a slower release of $\mathrm{P}$ into the soil solution. These observations are reflected in the results of our own studies in which thermal conversion of pig manure and poultry litter did not cause an increase in the contents of water-extracted $\mathrm{P}$ forms. The temperature used in the tests was $300^{\circ} \mathrm{C}$, which is regarded by Song and Guo [32] as appropriate in the light of using biochar for agricultural purposes. As shown above, the process of thermal conversion of organic materials has generally decreased the contents of water-extracted forms of analysed elements compared to their total contents.

Soil pH, Hydrolytic Acidity (Hh), Sum of Exchangeable Alkaline Cations (EAC), Cation Exchange Capacity (CEC), and Base Saturation (BS) after the Organic Material Applications

Soil $\mathrm{pH}$ is the primary factor influencing the mobility and assimilability of nutrients; therefore, the biochar

Table 3. K, Mg and P contents in pig manure, poultry litter and biochars.

\begin{tabular}{|c|c|c|c|c|}
\hline Determination & $\begin{array}{c}\text { Pig manure } \\
(\mathrm{PM})\end{array}$ & $\begin{array}{c}\text { Pig manure - derived } \\
\text { biochar (BPM) }\end{array}$ & $\begin{array}{c}\text { Poultry litter } \\
(\mathrm{PL})\end{array}$ & $\begin{array}{c}\text { Poultry litter - derived } \\
\text { biochar (BPL) }\end{array}$ \\
\hline Total $\mathrm{K}\left(\mathrm{g} \cdot \mathrm{kg}^{-1}\right)$ & $21.2 \pm 0.1$ & $42.3 \pm 0.4$ & $23.3 \pm 0.2$ & $38.3 \pm 1.6$ \\
\hline $\mathrm{K}-\mathrm{H}_{2} \mathrm{O}\left(\mathrm{g} \cdot \mathrm{kg}^{-1}\right)$ & $17.8 \pm 0.2$ & $19.9 \pm 0.6$ & $16.4 \pm 0.8$ & $17.6 \pm 0.2$ \\
\hline Share of $\mathrm{K}-\mathrm{H}_{2} \mathrm{O}$ in Total K $(\%)$ & 83.9 & 47.0 & 70.4 & 45.9 \\
\hline Total $\mathrm{Mg}\left(\mathrm{g} \cdot \mathrm{kg}^{-1}\right)$ & $4.70 \pm 0.10$ & $10.1 \pm 0.7$ & $8.50 \pm 0.70$ & $13.7 \pm 0.3$ \\
\hline $\mathrm{Mg}-\mathrm{H}_{2} \mathrm{O}\left(\mathrm{g} \cdot \mathrm{kg}^{-1}\right)$ & $1.70 \pm 0.05$ & $0.85 \pm 0.02$ & $1.74 \pm 0.05$ & $0.74 \pm 0.01$ \\
\hline Share of $\mathrm{Mg}-\mathrm{H}_{2} \mathrm{O}$ in Total Mg $(\%)$ & 36.1 & 8.4 & 20.4 & 5.4 \\
\hline Total P $\left(\mathrm{g} \cdot \mathrm{kg}^{-1}\right)$ & $10.2 \pm 0.7$ & $20.5 \pm 1.9$ & $18.3 \pm 2.2$ & $27.6 \pm 2.9$ \\
\hline $\mathrm{P}-\mathrm{H}_{2} \mathrm{O}\left(\mathrm{g} \cdot \mathrm{kg}^{-1}\right)$ & $5.11 \pm 0.06$ & $5.15 \pm 0.09$ & $4.80 \pm 0.03$ & $3.92 \pm 0.12$ \\
\hline Share of $\mathrm{P}-\mathrm{H}_{2} \mathrm{O}$ in Total P $(\%)$ & 50.0 & 25.1 & 26.2 & 14.2 \\
\hline
\end{tabular}


application in soil may indirectly affect these processes by changing soil $\mathrm{pH}$ [33]. The $\mathrm{pH}$ values determined in the suspensions of soil and water, and soil and $\mathrm{KCl}$ solution depended on the type and amount of the material used (Figs 1-2). The application of organic materials resulted in a significant reduction in soil acidification.

It has been observed that the $\mathrm{pH}$ values determined for both soil and water suspension, and suspension made of soil and $\mathrm{KCl}$ solution increased together with an increased dose of organic material. Comparing the effect of pig manure (PM) and poultry litter (PL) with biochars (BPM, BPL) derived from these materials, biochars were found to have a significantly better deacidifying effect. The best deacidifying effect was achieved after adding $1 \%$ and $2 \%$ of biochar. The obtained results of our own

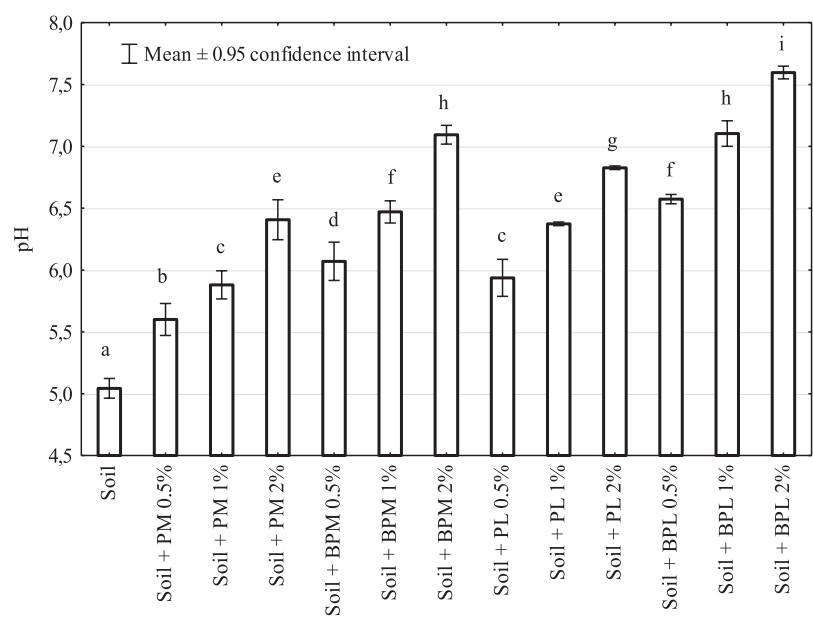

Fig. 1. Soil $\mathrm{pH}$ (soil and water suspension). Mean values marked within the same letters do not differ significantly according to Tukey's t-test at $\mathrm{p} \leq 0.05$.

PM - pig manure, BPM - pig manure - derived biochar, PL - poultry litter, BPL - poultry litter - derived biochar

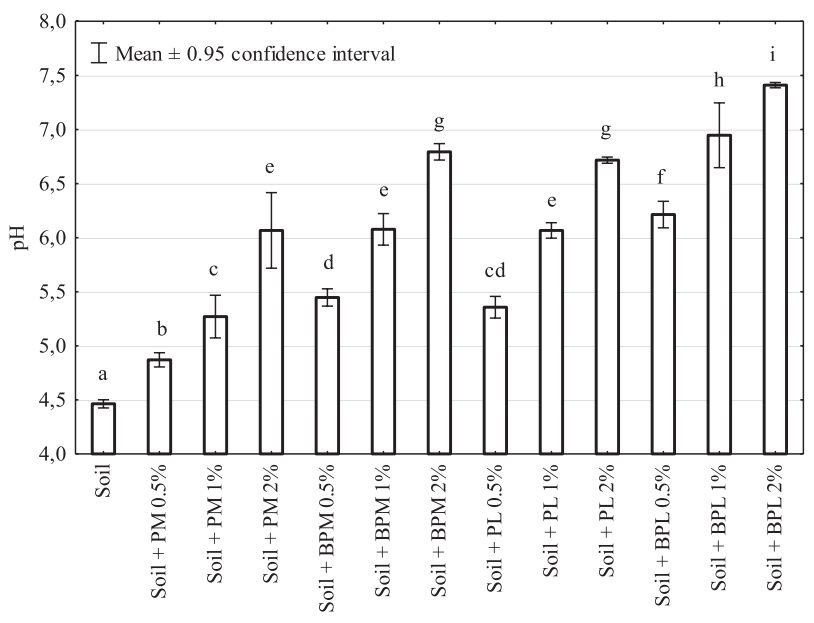

Fig. 2. Soil $\mathrm{pH}$ (suspension of the soil and $1 \mathrm{M} \mathrm{KCl}$ solution). Mean values marked within the same letters do not differ significantly according to Tukey's t-test at $\mathrm{p} \leq 0.05$

PM - pig manure, BPM - pig manure - derived biochar, PL - poultry litter, BPL - poultry litter - derived biochar. studies confirm the findings of Yuan et al. [34], according to which alkaline substances are easier released from biochars than from materials not subjected to thermal conversion. The biochar chemical properties undergo substantial changes as a result of thermal conversion. The organic compounds decrease in favour of mineral connections, which exhibit a greater potential for soil deacidification [34]. Furthermore, there is an increase in the contents of calcium and magnesium carbonates and cations, which are easily converted into the soil solution [35]. Yuan et al. [34] and Masud et al. [36] also presented evidence that soil $\mathrm{pH}$ increases by 0.4 to 1.2 units in sandy and clay soils after adding biochar. According to Cheng et al. [37], the biochar application does not always favour the process of soil deacidification. The application of biochar to soils may contribute to the release of acidifying substances through chemical and microbiological processes. The probability of such a situation in a short time (four months after the application) is confirmed by the result obtained by Liu and Zhang [38].

The $\mathrm{Hh}$ values determined in the soil depended on the type and amount of the organic material used (Table 4). The application of biochars (BPM, BPL) resulted in a significant reduction in the value of soil hydrolytic acidity. It has been observed that the Hh values decreased with an increased dose of organic material. Comparing the Hh value in soil with the highest dose of organic materials $(2 \%)$ with the value determined in control soil, the reduced hydrolytic acidity values were found to be $39.6 \%$ for pig manure (PM) and $58.1 \%$ for pig manurederived biochar (BPM), and $62.3 \%$ for poultry litter (PL) and $75.3 \%$ for poultry litter-derived biochar (BPL). The reduced soil hydrolytic acidity after biochar application was also noted by Masud et al. [36]. The above authors justified this phenomenon with the formation of surface complexes of $\mathrm{Al}^{3+}$ with functional groups present on the biochar surface.

The sum of exchangeable alkaline cations (EAC) was higher in each treatment with organic material applied when compared to the control treatment (Table 4). The introduction of biochar into the soil caused a significantly higher increase in the EAC value compared to the same dose of non-converted organic material. It should also be noted that poultry litter (PL) and poultry litter-derived biochar (BPL) were more effective in increasing the sum of exchangeable alkaline cations than pig manure (PM) and pig manure-derived biochar (BPM).

The highest increase in CEC was found after the application of both biochars (BPM, BPL) rather than pig manure (PM) and poultry litter (PL). It has been noted that the increase in the CEC value was related to the amount of organic material added. As stated by Glaser et al. [39], the proportionality of CEC increase to the amount of biochar introduced into the soil is due to the increased number of alkaline cations in the soil solution. This enters rapidly to the equilibrium with the adsorption surface of the colloids by electrostatic forces. On the other hand, Yuan et al. [34] believed that the cause of a substantial increase in CEC after 
Table 4. Hydrolytic acidity (Hh), sum of exchangeable alkaline cations (EAC), cation exchange capacity (CEC) and base saturation (BS) of soil after the organic material applications.

\begin{tabular}{|c|c|c|c|c|}
\hline \multirow{2}{*}{ Treatment } & Hh & EAC & CEC & BS \\
\cline { 2 - 5 } & \multicolumn{3}{|c|}{ mmol $(+) \cdot \mathrm{kg}^{-1}$} & $73.4 \pm 1.9 \mathrm{a}$ \\
\hline Soil & $23.67 \pm 2.02^{\mathrm{f}}$ & $65.1 \pm 2.5^{\mathrm{a}}$ & $88.8 \pm 2.9^{\mathrm{a}}$ & $80.0 \pm 0.8 \mathrm{~b}$ \\
\hline Soil + PM 0.5\% & $18.58 \pm 1.23^{\mathrm{e}}$ & $74.3 \pm 1.4^{\mathrm{ab}}$ & $92.9 \pm 2.7^{\mathrm{ab}}$ & $83.0 \pm 0.4 \mathrm{bc}$ \\
\hline Soil + PM 1\% & $17.05 \pm 0.44^{\mathrm{e}}$ & $83.5 \pm 2.9^{\mathrm{bcd}}$ & $100.6 \pm 3.1^{\mathrm{ab}}$ & $86.0 \pm 3.5 \mathrm{cde}$ \\
\hline Soil + PM 2\% & $15.01 \pm 3.24^{\mathrm{de}}$ & $92.6 \pm 6.6^{\mathrm{cd}}$ & $107.6 \pm 3.8^{\mathrm{bc}}$ & $82.2 \pm 1.3 \mathrm{bc}$ \\
\hline Soil + BPM 0.5\% & $16.55 \pm 0.44^{\mathrm{e}}$ & $76.8 \pm 5.2^{\mathrm{abc}}$ & $93.4 \pm 4.8^{\mathrm{ab}}$ & $87.8 \pm 1.7 \mathrm{def}$ \\
\hline Soil + BPM 1\% & $12.49 \pm 0.88^{\mathrm{cd}}$ & $90.3 \pm 9.0^{\mathrm{bcd}}$ & $102.8 \pm 8.4^{\mathrm{ab}}$ & $91.7 \pm 0.9 \mathrm{fg}$ \\
\hline Soil + BPM 2\% & $9.93 \pm 1.15^{\mathrm{bc}}$ & $110.2 \pm 0.0^{\mathrm{e}}$ & $120.1 \pm 1.1^{\mathrm{c}}$ & $84.3 \pm 1.1 \mathrm{~cd}$ \\
\hline Soil + PL 0.5\% & $15.66 \pm 0.38^{\mathrm{de}}$ & $84.4 \pm 7.2^{\mathrm{bcd}}$ & $100.1 \pm 7.2^{\mathrm{ab}}$ & $89.3 \pm 0.8 \mathrm{ef}$ \\
\hline Soil + PL 1\% & $11.21 \pm 0.58^{\mathrm{c}}$ & $93.6 \pm 3.8^{\mathrm{d}}$ & $104.8 \pm 3.6^{\mathrm{bc}}$ & $93.5 \pm 0.6 \mathrm{gh}$ \\
\hline Soil + PL 2\% & $8.93 \pm 0.58^{\mathrm{abc}}$ & $128.1 \pm 11.0^{\mathrm{f}}$ & $137.0 \pm 11.1^{\mathrm{d}}$ & $90.1 \pm 0.2 \mathrm{efg}$ \\
\hline Soil + BPL 0.5\% & $9.77 \pm 0.37^{\mathrm{bc}}$ & $88.6 \pm 1.4^{\mathrm{bcd}}$ & $98.4 \pm 1.8^{\mathrm{ab}}$ & $94.1 \pm 0.4 \mathrm{gh}$ \\
\hline Soil + BPL 1\% & $7.00 \pm 0.58^{\mathrm{ab}}$ & $111.9 \pm 1.4^{\mathrm{ef}}$ & $118.9 \pm 1.9^{\mathrm{c}}$ & $96.5 \pm 0.4 \mathrm{~h}$ \\
\hline Soil + BPL 2\% & $5.86 \pm 0.80^{\mathrm{a}}$ & $163.9 \pm 6.3^{\mathrm{g}}$ & $169.8 \pm 6.6^{\mathrm{e}}$ & \\
\hline
\end{tabular}

Each value represents the mean of three replicates \pm standard deviation. The different letters within a column indicate a significant difference at $p \leq 0.05$ according to Tukey's multiple range tests

PM - pig manure, BPM - pig manure - derived biochar, PL - poultry litter, BPL - poultry litter - derived biochar

the introduction of biochar into the soil was the presence of negatively charged surface functional groups of the material. The quoted authors showed that the CEC values of biochar itself are 10 to 20 times higher than the soil CEC value. In the course of their incubation tests, Yuan et al. [34] also reported that the CEC value of soil with introduced $1-2 \%$ of biochar increased considerably. A similar theory was presented in the study by Wang et al. [40]. The authors demonstrated that biochar added to acidic soil contributes to a significant increase in exchangeable alkaline cations and reduction in exchangeable acidity due to the process of decarboxylation and bonding of $\mathrm{H}^{+}$ions with biochar functional groups.

Regardless of the material used, an increase in base saturation (BS) was observed in each treatment (Table 4). As in the case of EAC and CEC, higher values of the parameter were noted at higher doses of organic materials. Comparing the effect of pig manure (PM) with the one of poultry litter (PL), the poultry litter application proved to induce higher BS values. A similar relation was found for the application of pig manure-derived and poultry litter-derived biochars. Da Silva Mendes et al. [41] also showed similar values of base saturation to those obtained in this study (80\%), after adding $1-2 \%$ of poultry litter-derived biochar.

Many authors have confirmed the beneficial effect of biochar on the soil cation exchange capacity value [14, 34, 42]. As emphasised by Brodowski et al. [43] and Cheng et al. [37], this parameter plays a crucial role in the retention of water and nutrients for plants. This beneficial effect of biochar on the soil cation exchange capacity can be attributed to its physical properties, and in particular to its porous structure and specific surface area [9, 44]. In turn, Lehmann [45] stated that biochars produced at a temperature below $400^{\circ} \mathrm{C}$, depending on the materials and production conditions, can have low CEC values and, consequently, limited effect on the improvement of soil quality. However, the author emphasised that despite the low CEC values, biochar undergoes an aging process in the soil, which in turn causes an increase in that parameter.

\section{Available K, Mg, and P in Soil after Organic Material Applications}

The content of available forms of potassium was significantly higher in the soil of all treatments with applied organic materials compared to assimilable $\mathrm{K}$ content determined in the control soil (Table 5). The addition of both pig manure (PM) and poultry litter (PL), regardless of their doses, resulted in a smaller increase in the content of available forms of potassium than the addition of pig manure-derived and poultry litter-derived biochars (BPM, BPL). Comparing the impact of materials not subjected to thermal conversion (PM, PL) with those thermally converted (BPM, BPL) it is concluded that the addition of pig manure-derived biochar (BPM) caused an increase in available $\mathrm{K}$ content. For $0.5 \%, 1 \%$, and $2 \%$ doses, the increase was $30 \%, 37 \%$ and $40 \%$, respectively. In the case of the addition of poultry litter-derived biochar (BPL), the calculated increase was lower compared to 
Table 5. Available K, Mg and P of soil after the organic material applications.

\begin{tabular}{|c|c|c|c|}
\hline \multirow{2}{*}{ Treatment } & $\mathrm{K}$ & $\mathrm{Mg}$ & $\mathrm{P}$ \\
\hline & \multicolumn{3}{|c|}{$\mathrm{mg} \cdot \mathrm{kg}^{-1}$} \\
\hline Soil & $33.2 \pm 6.4^{\mathrm{a}}$ & $49.9 \pm 3.6^{\mathrm{a}}$ & n.d. ${ }^{\text {a) }}$ \\
\hline Soil + PM 0.5\% & $125.0 \pm 6.6^{\mathrm{b}}$ & $96.2 \pm 11.1^{\mathrm{bc}}$ & n.d. \\
\hline Soil + PM 1\% & $224.0 \pm 7.7^{\mathrm{ef}}$ & $107.9 \pm 28.9^{\mathrm{bc}}$ & n.d. \\
\hline Soil + PM 2\% & $449.3 \pm 16.6^{\mathrm{i}}$ & $142.8 \pm 5.9^{\mathrm{de}}$ & n.d. \\
\hline Soil + BPM 0.5\% & $163.2 \pm 9.4^{\mathrm{cd}}$ & $79.0 \pm 3.9^{\mathrm{ab}}$ & n.d. \\
\hline Soil + BPM 1\% & $307.6 \pm 3.5^{\mathrm{g}}$ & $111.2 \pm 5.5^{\mathrm{cd}}$ & n.d. \\
\hline Soil + BPM 2\% & $632.4 \pm 25.5^{\mathrm{k}}$ & $156.7 \pm 7.0^{\mathrm{e}}$ & $3.58 \pm 0.45^{\mathrm{b}}$ \\
\hline Soil + PL $0.5 \%$ & $122.1 \pm 8.0^{\mathrm{b}}$ & $78.5 \pm 5.6^{\mathrm{ab}}$ & n.d. \\
\hline Soil + PL 1\% & $191.6 \pm 13.3^{\mathrm{de}}$ & $96.4 \pm 6.6^{\mathrm{bc}}$ & n.d. \\
\hline Soil + PL 2\% & $391.3 \pm 0.6^{\mathrm{h}}$ & $149.5 \pm 10.6^{\mathrm{e}}$ & $3.02 \pm 0.19^{\mathrm{a}}$ \\
\hline Soil + BPL 0.5\% & $133.9 \pm 8.8^{\mathrm{bc}}$ & $94.4 \pm 8.2 b^{c}$ & n.d. \\
\hline Soil + BPL 1\% & $235.0 \pm 21.6^{\mathrm{f}}$ & $109.2 \pm 11.5^{\mathrm{bc}}$ & n.d. \\
\hline Soil + BPL 2\% & $525.6 \pm 13.7^{j}$ & $162.2 \pm 3.6^{\mathrm{e}}$ & $7.19 \pm 0.24^{\mathrm{c}}$ \\
\hline
\end{tabular}

Each value represents the mean of three replicates \pm standard deviation. The different letters within a column indicate a significant difference at $p \leq 0.05$ according to Tukey's multiple range tests

a)n.d. - not determined

PM - pig manure, BPM - pig manure - derived biochar, PL - poultry litter, BPL - poultry litter - derived biochar

converted poultry litter (PL), and amounted to $9 \%, 22 \%$, and $34 \%$ respectively.

The contents of available forms of magnesium and potassium in the soil have substantially increased after the organic material applications (from $57 \%$ to $225 \%$ ) compared to the contents determined in the control soil (Table 5). The increase in available magnesium contents was proportional to the amount of organic material introduced. In general, larger increases in available $\mathrm{Mg}$ content were recorded after applying both biochars (BPM, BPL) rather than pig manure (PM) and poultry litter (PL).

Available forms of phosphorus were found neither in the soil before the tests, nor in most treatments used in the experiment (Table 5 ). Only a $2 \%$ dose of pig manurederived biochar (BPM) and poultry litter (PL), as well as poultry litter-derived biochar (BPL) caused the release of available forms of $\mathrm{P}$.

The studies conducted by Larid et al. [14] have found an increase in the contents of available forms of phosphorus and potassium, which was contingent upon the amount of biochar added to the soil. According to the quoted authors, the application of biochar into the soil had no impact on the content of available forms of magnesium. The studies conducted by Park et al. [46], Luo et al. [47], and Sigua et al. [48] discovered that the application of biochar into the soil resulted in a distinct increase of the potassium, phosphorus, and magnesium contents in the soil. According to the results of our own tests, the available potassium and magnesium contents showed an increase with increased doses of both pig manure-derived and poultry litter-derived biochars. Most likely, this was due to a large load of these elements introduced to the soil with biochar. Our own studies confirmed no available forms of phosphorus in the soil into which lower $(0.5 \%$ and $1 \%)$ doses of biochars were introduced. Only the highest (2\%) biochar dose caused the release of available $\mathrm{P}$. This situation might be due to a very strong chemical adsorption of phosphates. It should be noted that soil $\mathrm{pH}$ values increased along with the increased biochar dose, which effectively weakened the chemical processes causing the release of P. The studies conducted by Parvage et al. [49] have shown that the highest concentration of water-soluble $\mathrm{P}$ was obtained with $1 \%$ of biochar added to the soil. In our own studies, the content of available forms of $\mathrm{P}$ was determined in treatments to which the highest dose $(2 \%)$ of biochar was added. The studies by Pavage et al. [49] have found that higher doses of biochar increase soil $\mathrm{pH}$, which can lead to a reduction of available forms of the element. According to the quoted authors, the reason for this phenomenon lies in reactions of $\mathrm{P}$ with calcium and magnesium ions, which can be released from biochar. On the other hand, Zhai et al. [50] explained it by the increase in the content of assimilable phosphorus after adding higher doses of biochar.

\section{Conclusions}

Thermal conversion of pig manure and poultry litter increased the content of total forms of $\mathrm{K}, \mathrm{Mg}$, 
and $\mathrm{P}$ in biochars and decreased the share of these elements extracted by water in the total content. The introduction of organic materials, in particular biochar, into the soil caused significant reduction in soil acidification and an increase in cation exchange capacity. The contents of available potassium and magnesium increased together with the increase in dose of pig manure-derived and poultry litter-derived biochars. No available forms of phosphorus were found in the soil into which lower $(0.5 \%$ and $1 \%)$ doses of biochar were introduced. Only the highest $(2 \%)$ dose of biochars and poultry litter caused the release of available $\mathrm{P}$.

\section{Acknowledgements}

Our research was financed by the Ministry of Science and Higher Education of the Republic of Poland.

\section{Conflict of Interest}

The authors declare no conflict of interest.

\section{References}

1. YAO Y., GAO B., ZHANG M., INYANG M., ZIMMERMAN A.R. Effect of biochar amendment on sorption and leaching of nitrate, ammonium, and phosphate in a sandy soil. Chemosphere, 89, 1467, 2012.

2. SAPEK A. Original research magnitude of nitrogen and phosphorus delivered to Baltic Sea via Polish rivers. Pol. J. Environ. Stud., 23 (6), 2191, 2014.

3. ZHENG S., XIAO M., MIAO Z. Nitrogen losses in paddy field drainage modified by different water level regulations. Pol. J. Environ. Stud., 26 (3), 1393, 2017.

4. CHOUDHARY M., BAILEY L.D., GRANT C.A. Review of use of swine manure in crop production: effect on yield composition and on soil and water quality. Waste Manag. Res., 14 (6), 581, 1996.

5. DEMIR K., SAHIN O., KADIOGLU Y.K., PILBEAM D.J., GUNES A. Essential and non-essential element composition of tomato plants fertilized with poultry manure. Scientia Horticulturae, 127, 16, 2010.

6. BHOI L., MISHRA P.CH. Changes in bacterial density, $\mathrm{CO}_{2}$ evolution and enzyme activities in poultry dung amended soil. Open Journal of Soil Science, 2, 196, 2012.

7. SENKONDO Y.H., TACK F.M.G., SEMU E. Influence of farm yard manure, poultry manure and forest litter on copper solubility in soil and uptake by Phaseolus vulgaris. Soil Use Managem., 30 (4), 480, 2014.

8. ARTHUR E., TULLER M., MOLDRUP P., DE JONGE L.W. Effects of biochar and manure amendments on water vapor sorption in a sandy loam soil. Geoderma, 243-244, 175, 2015.

9. ATKINSON C.J., FITZGERALD J.D., HIPPS N.A. Potential mechanisms for achieving agricultural benefits from biochar application to temperate soil: a review. Plant and Soil. 337, 1, 2010.

10. BARONTI S., VACCARI F.P., MIGLIETTA F., CALZOLARI C., LUGATO E., ORLANDINI .S, PINI R., ZULIAN C., GENESIO L. Impact of biochar application on plant water relations in Vitis vinifera (L.). Eur J Agron., 53, 38, 2014.

11. SLAVICH P.G., SINCLAIR K., MORRIS S.H., KIMBER S.W.L., DOWNIE A., VAN ZWIETEN L. Contrasting effects of manure and green waste biochars on the properties of an acidic ferralsol and productivity of asubtropical pasture. Plant Soil, 366, 213, 2013.

12. LEHMANN J., JOSEPH S. Biochar for environmental management: an introduction. In: Lehmann J., Joseph S. (Eds.), Biochar for Environmental Management: Science and Technology. Earthscan, London. 12, 2009.

13. BAI S.H., XU CH.Y., XU Z., BLUMFIELD T.J., ZHAO H., WALLACE H., REVERCHON F., ZWEITEN L.V. Soil and foliar nutrient and nitrogen isotope composition $\left(\delta{ }^{15} \mathrm{~N}\right)$ at 5 years after poultry litter and green waste biochar amendment in a macadamia orchard. Environ Sci Pollut Res., 22, 3803, 2015.

14. LARID D., FLEMING P., WANG B., HORTON R., KARLEN D. Biochar impact of nutrient leaching from a Midwestern agricultural soil. Geoderma, 158 (3-4), 436, 2010.

15. SOHI S., KRULL E., LOPEZ-CAPEL E., BOL R. A review of biochar and its use and function in soil. Advances in Agronomy, 105, 47, 2010.

16. LIN Y., MUNROE P., JOSEPH S., HENDERSON R., ZIOLKOWSKI A. Water extractable organic carbon in untreated and chemical treated biochar. Chemosphere, 87, 151, 2012.

17. AKÇA M.O., NAMLI A. Effects of poultry litter biochar on soil enzyme activities and tomato, pepper and lettuce plants growth. Eurasian J Soil Sci., 4 (3), 161, 2015.

18. IBI. Standardized Product Definition and Product Testing Guidelines for Biochar that Is Used in Soil. (cited 14 March, 2015), 2012.

19. LU H., ZHANG W., WANG S., ZHUANG L., YANG Y., QIU R. Characterization of sewage sludge-derived biochars from different feedstocks and pyrolysis temperatures. J. Anal. Appl. Pyrolysis, 102, 137, 2013.

20. MENDEZ A., TERRADILLOS M., GASCO G. Physicochemical and agronomic properties of biochar from sewage sludge pyrolysed at different temperatures. J. Anal. Appl. Pyrolysis., 102, 124, 2013.

21. GONDEK K., BARAN A., KOPEĆ M. The effect of lowtemperature transformation of mixtures of sewage sludge and plant materiale on content, leachability and toxicity of heavy metals. Chemosphere, 117, 33, 2014.

22. DOMENE X., ENDERS A., HANLEY K., LEHMANN J. Ecotoxicological chracteryzation of biochars: Role of feedstock and pyrolysis temperature. Sci. Total Environment., 512-513, 552, 2015.

23. ZIELIŃSKA A., OLESZCZUK P., CHARMAS B., SKUBISZEWSKA-ZIĘBA J., PIASECZNAPATKOWSKA S. Effect of sewage sludge properties on the biochor chracteristic. J. Analytical Applied Pyrolysis, 112, 201, 2015.

24. JINDO K., SUTO K., MATSUMOTO K., GARCIA C., SONOKI T., SANCHEZ-MONEDERO M.A. Chemical and biochemical chracterisation of biochar-blended composts prepared from poultry manure. Biores. Technol., 110, 396, 2012.

25. MEIER S., CURAQUEO G., KHAN N., BOLAN N., RILLING J., VIDAL C., FERNÁNDEZ N., ACUNA J., GONZÁlEZ M.E., CORNEJO P., BORIE F. Effect of biochar on copper immobilization and soil microbial 
communities in a metal-contaminated soil. J. Soils Sediments., 14, 2015.

26. OLESZCZUK P. The evaluation of sewage sludge and compost toxicity to Heterocypris incongruens in relation to inorganic and organic contaminants content. Environ. Toxicol., 22 (6), 587, 2007.

27. BARRET E.P., JOYNER L.G., HALENDA P.H. The determination of pore volume and area distributions in porous substances. I. Computations from nitrogen isotherms. J. Amer. Chem. Soc., 73 (1), 373, 1951.

28. JAREMKO D., KALEMBASA D. A comparison of method for the determination of cation exchange capacity of soils. Ecol. Chem. Eng. S., 21 (3), 487, 2014.

29. HOUBA V.J.G., NOVOZAMSKY I. TEMMINGHOFF E. Soil analysis procedur es. Extraction with $0,01 \mathrm{M} \mathrm{CaCl}_{2}$. Soil Plant Anal., 5 (A), 66, 1994.

30. GASKIN J.W., STAINER C., HARRIS K., DAS K.C., BIBENS B. Effect of low - temperature pyrolysis conditions on biochar for agricultural use. Transaction of the ASABE, 51 (6), 2061, 2008.

31. WANG Y., LIN Y., CHIU P.C., IMHOFF P.T., GUO M. Phosphorus relase behaviors of poultry litter biochar as a soil amendment. Sci. Total Environ., 512-513, 454, 2015.

32. SONG W., GUO M. Quality variations of poultry litter biochar generated at different pyrolysis temperatures. J. Anal. App. Pyrol., 94, 138, 2012.

33. LOSAK T., CERMAK P., HLUSEK J. Changes in fertilisation and liming of soils of the Czech Republic for the last 20 years. Archiv. Agronom. Soil Sci., 58 (1), 238, 2012.

34. YUAN J., XU R., WANG N., LI J. Amendment of acid soils with crop residues and biochars. Pedosphere, 21, 302, 2011.

35. VAN ZWIETEN L., KIMBER S., MORRIS S., CHAN K., DOWNIE A., RUST J., JOSEPH S., COWIE A. Effects of biochar from slow pyrolysis of papermill waste on agronomic performance and soil fertility. Plant Soil, 327, 235, 2010.

36. MASUD M.M., LI J.Y., XU R.K. Use of Alkaline Slag and Crop Residue Biochars to Promote Base Saturation and Reduce Acidity of an Acidic Ultisol. Pedosphere, 24 (6), 791, 2014.

37. CHENG C.H., LEHMANN J., THIES J.E., BURTON S.D., ENGELHARD M.H. Oxidation of black carbon by biotic and abiotic processes. Org. Geochem., 37, 477, 2006.

38. LIU Z., ZHANG F.S. Removal of lead from water Rusing biochars prepared from hydrothermal liquefaction of biomass. J. Hazard. Mat., 167, 933, 2009.

39. GLASER B., LEHMANN J., ZECH W. Ameliorating physical and chemical properties of highly weathered soils in the tropics with charcoal. A Review. J. Biol. Ferti. Soils., 35, 219, 2002.

40. WANG L., BUTTERLY C.R., WANG Y., HERATH H.M.S.K., XI Y.G., XIAO X.J. Effect of crop residue biochar on soil acidity amelioration in strongly acidic tea garden soils. Soil Use and Managem., 30 (1), 119, 2013.

41. DA SILVA MENDES J., GARÓFALO CHAVES L.H., FERNANDES J.D., DE BRITO CHAVES I. Using MB-4 rock powder, poultry litter biochar, silicate and calcium carbonate to amend different soil types. Australian Journal of Crop Science, 9 (10), 987, 2015.

42. FELLET G., MARCHIOL L., DELLE VEDOVE G., PERESSOTTI A. Application of biochar on mine tailings: Effects and perspectives for land reclamation. Chemosphere, 83, 1262, 2011.

43. BRODOWSKI S., AMELUNG W., HAUMAIER L., ABETZ C., ZECH W. Morphological and chemical properties of black carbon in physical soil fractions as revealed by scanning electron microscopy and energydispersive x-ray spectroscopy. Geoderma, 128, 116, 2005.

44. LEI Q., ZHANG R. Effects of biochars derived from different feedstocks and pyrolysis temperatures on soil physical and hydraulic properties. J. Soils Sediments, 13, 1561, 2013.

45. LEHMANN J. Bio-energy in the black. Frontiers in Ecology and the Environment. 5 (7), 381, 2007.

46. PARK H.J., CHOPPALA G.K., BOLAN N.S., CHUNG J.W., CHUASAVATHI T. Biochar reduces the bioavailability and phytotoxicity of heavy metals. Plant and Soil, 348, 439, 2011

47. LUO Y., JIAO Y., ZHAO X., LI G., ZHAO L., MENG $H$. Improvement to maize growth caused by biochars derived from six feedstocks prepared at three different temperatures. Journal of Integrative Agriculture, 13, 533, 2014.

48. SIGUA G.C., NOVAK J.M., WATTS D.W. Ameliorating soil chemical properties of a hard setting subsoil layer in Coastal Plain USA with different designer biochars. Chemospchere, 142, 168, 2016.

49. PARVAGE M.M., ULEN B., ERIKSSON J., STROCK J., KIRCHMANN H. Phosphorus availability in soil amended with wheat residue char. Biology and Fertility of Soils, 49 (2), 245, 2013.

50. ZHAI L., CAIJI Z., LIU J., WANG H., REN T., GAI X., XI B., LIU H. Short-term effect of maize residue biochar on phosphorus availability in two soils with different phosphorus sorption capacities. Biology and Fertility of Soils, 51 (1), 113, 2015. 
